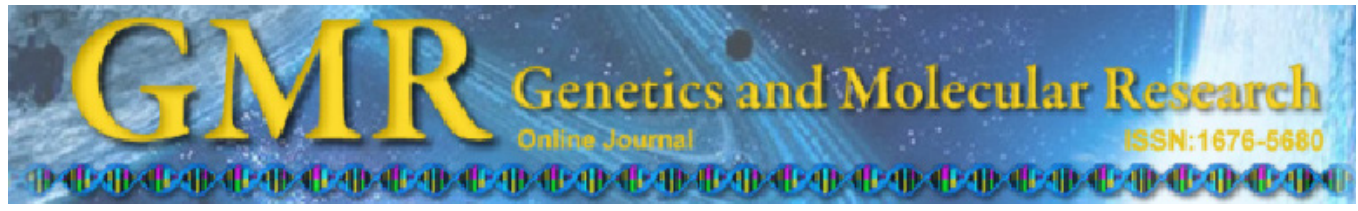

Short Communication

\title{
Characterization of eight novel microsatellite markers in the green-lipped mussel Perna viridis (Mytilidae)
}

Y.Y. Cao, Z.B. Li, Q.H. Li, X.J. Chen, L. Chen and G. Dai

Fisheries College, Institute of Aquaculture Biotechnology, Jimei University, Xiamen, China

Corresponding author: Z.B. Li

E-mail: lizhongbao@jmu.edu.cn

Genet. Mol. Res. 12 (1): 344-347 (2013)

Received February 16, 2012

Accepted August 29, 2012

Published February 7, 2013

DOI http://dx.doi.org/10.4238/2013.February.7.4

\begin{abstract}
The green lipped mussel, also known as the Asian green mussel (Perna viridis) is a fast reproducing and valuable food source, but it is also considered an invasive species and can clog and damage pipes and marine equipment. Eight novel polymorphic microsatellite loci for $P$. viridis were isolated and characterized. Microsatellite polymorphism was evaluated in 30 individuals collected from Xiamen, China. The number of alleles per locus and the polymorphism information content ranged from 2 to 5 and from 0.3092 to 0.7031 , respectively. The observed and expected heterozygosities were 0.1538 0.8400 and $0.1448-0.6833$, respectively. The loci identified in this study could provide a useful tool for the genetic population structure analysis of $P$. viridis.
\end{abstract}

Key words: Microsatellite; Perna viridis; Conservation genetics 


\section{INTRODUCTION}

The bivalve Perna viridis (Linnaeus), also called the green-lipped mussel, is mainly distributed along coastal waters throughout the Indo-Pacific to Japan. In China, it occurs naturally from the South Sea to the southern portion of the East Sea. It is an important species owing to its high commercial value as a cheap source of animal protein for human consumption (Nicholson and Lam, 2005). It is also extensively cultured in most Asian countries, including China, India, and Thailand, owing to its fast growth and high tolerance for various environmental stresses (Prakoon et al., 2010). In China, P. viridis, Mytilus coruscus, and M. edulis are considered the 3 most common aquaculture species in family Mytilidae.

$P$. viridis is widely used as a crucial biomonitor of heavy-metal pollution (Hamed and Emara, 2006) because it concentrate contaminants in its tissues, reflecting levels in the environment (Goldberg, 1975). Studies of $P$. viridis have focused mainly on its biomonitor character (Yap et al., 2005; Vijayavel, 2010), aquaculture (Sreenivasan et al., 1989), and genetic aspects (Lin et al., 2007; Ong et al., 2005, 2008, 2009). Ong et al. $(2005,2008)$ have reported 19 microsatellite markers that are dominant, whereas the 8 novel microsatellite markers we report herein are co-dominant.

\section{MATERIAL AND METHODS}

DNA was isolated from a single $P$. viridis individual captured in Xiamen, China. The genomic DNA was extracted using a gene DNA extraction kit SK 1252 (Sangon Biotech (Shanghai) Co., Ltd., Shanghai) according to manufacturer instructions. DNA concentration was estimated with electrophoresis on a $1 \%$ agarose gel and an ultraviolet spectrophotometer. A total volume of $2000 \mu \mathrm{g}(100 \mu \mathrm{g} / \mu \mathrm{L})$ genomic DNA was digested with $10 \mathrm{U} \mathrm{MboI}$ in a $25-\mu \mathrm{L}$ volume for $3 \mathrm{~h}$ (purifying a 200- to 1000-bp fraction), and then $20 \mu \mathrm{L}$ digested DNA was ligated to $\mathrm{MboI}$ adapter1 (5'-GATCGTCGACGGTACCGAATTCT-3') / MboI adapter2 (5'-GTCAAGAATTCGGTACCGTCGAC-3') using 5 U T4 DNA ligase in a $20-\mu \mathrm{L}$ volume. The digestion-ligation mixture was subsequently denatured and hybridized to $(\mathrm{CT})_{15}$ and (GT) ${ }_{15}$ biotinylated oligonucleotide probes, and fragments containing microsatellite repeats were captured with streptavidin MagneSphere Paramagnetic Particles (Promega). The recovered DNA fragments were amplified using $\mathrm{MboI}$ primer. After purification with GenCleanPCR (Generay), $4 \mu \mathrm{L}$ of the purified product was ligated to pMD19-T vector (Takara) at $16^{\circ} \mathrm{C}$ for $30 \mathrm{~min}$ and transformed into Escherichia coli for further selection on ampicillin plates. Positive colonies were transferred to 96 -well plates and further incubated at $37^{\circ} \mathrm{C}$ for $3 \mathrm{~h}$. The libraries were glycerolized and stored at $-20^{\circ} \mathrm{C}$.

Of 325 clones, 178 positive clones with DNA fragments above $500 \mathrm{bp}$ were chosen, cultured with shaking for $3 \mathrm{~h}\left(37^{\circ} \mathrm{C}, 300 \mathrm{rpm}\right)$, and sequenced. After sequence analysis, 134 clones were found to contain microsatellites (with 4 or more repetitions). Sixty-nine pairs of primers were successfully designed using Primer Premier 5.0 (Clarke and Gorley, 2001). Polymerase chain reaction amplification was carried out in a $10-\mu \mathrm{L}$ volume under the following conditions: predenaturation at $94^{\circ} \mathrm{C}$ for $5 \mathrm{~min}, 32$ cycles including denaturation at $94^{\circ} \mathrm{C}$ for $30 \mathrm{~s}$, annealing temperature (Table 1) for $30 \mathrm{~s}$, and elongation at $72^{\circ} \mathrm{C}$ for $30 \mathrm{~s}$, and a final extension at $72^{\circ} \mathrm{C}$ for $10 \mathrm{~min}$. The polymerase chain reaction products were electrophoresed on a Sequi-Gen Sequencing Cell (Bio-Rad, America), and the data matrix was analyzed using POPGENE32 and CERVUS 3.0 to estimate the basic genetic information index (see Table 1). 


\section{RESULTS AND DISCUSSION}

The results showed that the number of alleles per locus ranged from 2 to 5 and the polymorphism information content ranged from 0.3092 to 0.7031 . The observed and expected heterozygosities ranged from 0.1538 to 0.8400 and from 0.1448 to 0.6833 , respectively (see Table 1). Deviations from Hardy-Weinberg equilibrium and evaluated genotypic linkage disequilibrium were tested using POPGENE32 (Raymond and Rousset, 1995). No deviations from Hardy-Weinberg equilibrium were found in the tested population after Bonferroni's correction (adjusted $\mathrm{P}=0.00625$ ). MICRO-CHECKER was applied to verify microsatellite data (Van Oosterhout et al., 2004). These 8 novel microsatellite primers may provide useful information for further population structure studies and management in P. viridis.

\begin{tabular}{|c|c|c|c|c|c|c|c|c|c|}
\hline Locus ID & Primer sequences $\left(5^{\prime}-3^{\prime}\right)$ & $\begin{array}{c}\text { Annealing } \\
\text { temperature }\left({ }^{\circ} \mathrm{C}\right)\end{array}$ & Repeat motif & $N_{\mathrm{A}}$ & P-HWE & PIC & $N_{\mathrm{E}}$ & $H_{\mathrm{O}}$ & $H_{\mathrm{E}}$ \\
\hline$\overline{P V-6}$ & $\begin{array}{l}\text { F: ACCATTCAATGAAGAGGAT } \\
\text { R: GTTAAATAACAAAGACGTGTAA }\end{array}$ & 58 & $(\mathrm{CA})_{20}$ & 2 & 0.3922 & 0.4102 & 1.5283 & 0.2963 & 0.3522 \\
\hline PV-8 & $\begin{array}{l}\text { F: TACTGTTACAGGGAAGCG } \\
\text { R: AATGATGATTGGTTGGGT }\end{array}$ & 60 & $(\mathrm{GATT})_{4}$ & 2 & 0.0686 & 0.5564 & 1.7241 & 0.6000 & 0.4308 \\
\hline PV-18 & $\begin{array}{l}\text { F: TCCAAAGGTATAAACGAGGTA } \\
\text { R: TTCAAGCGAATAAGTTGGTAA }\end{array}$ & 56 & $(\mathrm{AG})_{88}$ & 4 & 0.0785 & 0.7031 & 3.0266 & 0.8400 & 0.6833 \\
\hline PV-21 & $\begin{array}{l}\text { F: TAACACTCCGTCTAAGAATC } \\
\text { R: GAGAAAGAAATCCGTGAATA }\end{array}$ & 50 & $(\mathrm{AC})_{21}$ & 2 & 0.7154 & 0.3092 & 1.1655 & 0.1538 & 0.1448 \\
\hline PV-25 & $\begin{array}{l}\text { F: CAAATAGAACGCTAGAAAA } \\
\text { R: CATTACATTGCTACCATGA }\end{array}$ & 40 & $(\mathrm{CA})_{33}$ & 4 & 0.0590 & 0.5421 & 1.8432 & 0.2917 & 0.4672 \\
\hline PV-26 & $\begin{array}{l}\text { F: TCAATGTACTGATTTCCTGTT } \\
\text { R: TTTGTCCTACCTTACCCAC }\end{array}$ & 48 & $(\mathrm{ATTG})_{3}$ & 2 & 0.7218 & 0.3318 & 1.7241 & 0.4000 & 0.4271 \\
\hline PV-44 & $\begin{array}{l}\text { F: GATCATACACCACTCACGC } \\
\text { R: ACATTTACAAAACCCAACA }\end{array}$ & 43 & $(\mathrm{AC})_{33}$ & 3 & 0.6631 & 0.4313 & 1.5267 & 0.4074 & 0.3515 \\
\hline PV-68 & $\begin{array}{l}\text { F: ACGATCTTGAACTTTGTG } \\
\text { R: CTCAGCGTAGGTTTTATT }\end{array}$ & 55 & $(\mathrm{AG})_{19} \mathrm{AC}(\mathrm{TG})_{19}$ & 5 & 0.0095 & 0.3270 & 1.5280 & 0.2667 & 0.3514 \\
\hline
\end{tabular}

$\mathrm{F}=$ forward primer; $\mathrm{R}=$ reverse primer; $N_{\mathrm{A}}=$ number of alleles per locus; $\mathrm{P}-\mathrm{HWE}=\mathrm{P}$ values for the HardyWienberg expectation test (adjusted $\mathrm{P}=0.00625$ ); $\mathrm{PIC}=$ polymorphic information content; $N_{\mathrm{E}}=$ effective number alleles per locus; $H_{\mathrm{O}}=$ observed and $H_{\mathrm{E}}=$ expected heterozygosities.

\section{ACKNOWLEDGMENTS}

Research supported by the Program for New Century Excellent Talents in Fujian Province University and the Foundation for Innovative Research Team of Jimei University, China (\#2010A004).

\section{REFERENCES}

Clarke KR and Gorley RN (2001). Primer Version 5. Primer-E, Plymouth.

Goldberg ED (1975). The mussel watch-a first step in global marine monitoring. Mar. Pollut. Bull. 6: 111.

Hamed MA and Emara AM (2006). Marine mollusks as biomonitors for heavy metal levels in the Gulf of Suez, Red Sea. J. Mar. Syst. 60: 220-234.

Lin G, Feng F and Yue GH (2007). Isolation and characterization of polymorphic microsatellites from Asian green mussel (Perna viridis). Mol. Ecol. Notes 7: 1036-1038.

Nicholson S and Lam PK (2005). Pollution monitoring in Southeast Asia using biomarkers in the mytilid mussel Perna viridis (Mytilidae: Bivalvia). Environ. Int. 31: 121-132. 
Ong CC, Tan SG and Yusof K (2005). Isolation of DNA microsatellite markers in the green-lipped mussel, Perna viridis. Pertanika J. Trop. Agric. Sci. 28: 79-85.

Ong CC, Teh CH, Tan SG, Yusoff K, et al. (2008). Eleven novel polymorphic microsatellite DNA markers from the greenlipped mussel Perna viridis. Genetika 44: 574-576.

Ong CC, Yusoff K, Yap CK and Tan SG (2009). Genetic characterization of Perna viridis L. in peninsular Malaysia using microsatellite markers. J. Genet. 88: 153-163.

Prakoon W, Tunkijjanukij S, Nguyen TT and Na-Nakorn U (2010). Spatial and temporal genetic variation of green mussel, Perna viridis in the Gulf of Thailand and implication for aquaculture. Mar. Biotechnol. 12: 506-515.

Raymond M and Rousset F (1995). GENEPOP (version 1.2) population genetics software for exact tests and ecumenicism. J. Hered. 86: 248-249.

Sreenivasan PV, Thangavelu R and Poovannan P (1989). Biology of the green mussel, Perna viridis (Linnaeus) cultured in Muttukadu lagoon, Madras. Indian J. Fish. 26: 149-155.

Van Oosterhout C, Hutchinson WF, Wills DPM and Shipley P (2004). MICRO-CHECKER: software for identifying and correcting genotyping errors in microsatellite data. Mol. Ecol. Notes 4: 535-538.

Vijayavel K (2010). Water chemistry influences the toxicity of silver to the green-lipped mussel Perna viridis. Environ. Monit. Assess. 167: 289-295.

Yap CK, Ismail A and Tan SG (2005). Byssus of the green-lipped mussel Perna viridis (Linnaeus) as a biomonitoring material for Zn. Russ. J. Mar. Biol. 31: 102-108. 